\title{
Empirical Evidence on the Relation Between Stock Option Compensation and Risk Taking
}

\author{
Shivaram Rajgopal \\ Assistant Professor \\ Department of Accounting \\ University of Washington \\ Box 353200 \\ Seattle, WA 98195 \\ Tel: 2065437525 \\ Fax: 2066859392
}

E-mail: rajgopal@u.washington.edu

and

Terry Shevlin

Deloitte and Touche Professor

Department of Accounting

University of Washington

Box 353200

Seattle, WA 98195

Tel: 2065437223

Fax: 2066859392

E-mail: shevlin@u.washington.edu

October 2001

\footnotetext{
We thank Ross Watts and Ray Ball (the editors), an anonymous referee, Bob Bowen, Dave Burgstahler, Bill Cready, Wayne Guay, Jody Magliolo, Steve Matsunaga, Susan Moyer, Eric Noreen, Jeff Pontiff, Jean Schlinger, Jerry Zimmerman, and workshop participants at University of Chicago, Duke University, University of Oregon, Syracuse University, University of Washington, the $10^{\text {th }}$ annual Joint Conference on Accounting and Financial Economics held at the University of Texas-Austin, the 2000 Summer Symposium on Accounting Research at the Hong Kong University of Science and Technology, the 2000 European Finance Association meeting in London, and the 2000 American Accounting Association (AAA) meeting in Philadelphia for their comments on previous versions of this paper.
} 


\title{
Empirical Evidence on the Relation Between Stock Option Compensation and Risk Taking
}

\begin{abstract}
We examine whether executive stock options (ESOs) provide managers with incentives to invest in risky projects. For a sample of oil and gas producers, we examine whether the coefficient of variation of future cash flows from exploration activity (our proxy for exploration risk) increases with the sensitivity of the value of the CEO's options to stock return volatility (ESO risk incentives). Both ESO risk incentives and exploration risk are treated as endogenous variables by adopting a simultaneous equations approach. We find evidence that ESO risk incentives has a positive relation with future exploration risk taking. Additional tests indicate that ESO risk incentives exhibit a negative relation with oil price hedging in a system of equations where ESO risk incentives and hedging are allowed to be endogenously determined. Overall, our results are consistent with ESOs providing managers with incentives to mitigate risk-related incentive problems.
\end{abstract}




\section{Empirical Evidence on the Relation Between Stock Option Compensation and Risk Taking}

\section{Introduction}

A considerable body of theory posits that employee stock options (ESOs) offer incentives to risk-averse managers to invest in high-risk high-return projects on behalf of risk-neutral shareholders (e.g., Jensen and Meckling 1976; Haugen and Senbet 1981; Smith and Stulz 1985; Lambert 1986; Copeland and Weston 1988; Lambert, Larcker, and Verrecchia 1991; Hirshleifer and Suh 1992; Murphy 1998; and Hemmer, Kim, and Verrecchia 1999). However, there is little direct empirical evidence on whether ESOs affect managers' decisions to undertake more risky but positive net present value and hence firm-value-increasing projects. In this study, we provide such evidence.

We investigate the influence of ESO risk incentives on actions that CEOs of oil and gas firms take to manage an important risk factor - the risk of uncertain success in exploring for new oil and gas reserves (exploration risk). ${ }^{\square}$ The relation between ESO risk incentives and the decision to manage operating risk (such as risk related to exploration activities) has not been explicitly addressed by prior studies, likely due to data constraints. Recently improved proxy disclosures enable assessment of the dollar magnitude of incentives provided to the CEO by the convex payoffs of her ESOs to increase firm risk (specifically stock return volatility). The dollar magnitude of such incentives (hereafter, ESO risk incentives) is computed as the partial derivative of the Black-Scholes option pricing function with respect to stock return volatility (see Guay 1999).

Additionally, Barth (1998) notes that extant disclosures generally are inadequate for researchers to determine the magnitude of exposure to firm-specific operating risks.

\footnotetext{
${ }^{1}$ Exploration risk is an important risk that oil and gas producers face. Equity Research-Oil \& Gas Production (Bear Stearns, August 21, 1996, 21) states that the "two major risks in the E\&P (exploration and production) business are dry holes and commodity price swings." A maintained assumption is that there is a significant positive association between exploration risk and stock return volatility. We provide evidence
} 
However, accounting disclosures made by oil and gas producers make it possible to derive measures of risk arising from exploration activity. Specifically, we use a model developed by Sunder (1976) to estimate the coefficient of variation (the variance/mean) in expected future cash flows arising from exploration - our proxy for exploration risk. A benefit of the Sunder model is that the firm-specific annual exploration risk measure can be estimated using a single year of data, unlike more conventional measures of mean and variance that require a time-series of data.

If ESOs mitigate the risk-related incentive problem (defined as risk averse managers passing up positive but risky net present value (NPV) projects) by motivating managers to make high-risk investments, we should observe a positive association between ESO risk incentives and the coefficient of variation in future cash flows from exploration activity. We examine the relation between exploration risk taking and ESO risk incentives using a simultaneous equations model. This approach allows both exploration risk and ESO risk incentives to be treated as endogenous (or choice) variables. By using a simultaneous equations approach we can begin to address some of the inference problems about the relation between pay and performance when pay is treated as exogenous (e.g., Larcker 1983). We find significant positive associations between the endogenously determined ESO risk incentives and exploration risk consistent with ESOs providing incentives to increase firm risk. However, we find no evidence that exploration risk is a determinant of the level of ESO risk incentives offered by the firm. Additional tests indicate that the relation between ESO risk incentives and the extent of oil price risk managed (hedged), another potentially important risk taking activity in oil and gas firms, is negative in a simultaneous equations framework where ESO risk incentives and hedging

consistent with this assumption in section 3.4. We investigate the relation between oil price risk and ESO risk incentives in section 4.2 . 
are treated as endogenous variables. This negative relation is also consistent with ESOs providing incentives to increase firm risk.

Our study is among the first to document a direct link between ESO risk incentives and variance-increasing investments while explicitly recognizing that ESO risk incentives are endogenously determined.2 Our work is related to Guay (1999). Similar to Guay, we consider two issues: 1) the determinants of the level of ESO risk incentives and 2) the impact of incentives on firm risk. Guay focuses on the first issue and only loosely examines the impact of ESO incentives on firm risk - by documenting a positive contemporaneous association between ESO risk incentives and stock return volatility. We rely on Guay's model of the determinants of ESO risk incentives to control for endogeneity in order to focus on the second issue - the impact on managers' risk-taking activity of the risk incentives provided by ESOs. We examine the incentives that ESOs offer for assuming a very specific risk that is important for a particular group of firms exploration risk. Thus while Guay analyzes the determinants of ESO risk incentives, we provide more powerful tests of the association between ESO risk incentives and CEO's risk-taking activities.

As pointed out by Indjejikian (1999), managerial accounting research has long aimed at understanding the impact of risky pay on managerial behavior. We further such understanding by documenting an association between ESO risk incentives and explicit managerial risk-taking actions. Evidence on the impact of ESOs on risk taking is

\footnotetext{
${ }^{2}$ Prior empirical work on this link (Agrawal and Mandelker 1987 and Defusco, Johnson, and Zorn 1990) suffers from three limitations. First, the cited papers measure risk incentives imposed by ESOs as the intrinsic value of the options or by the presence of an option plan. However, recent work by Core and Guay (1998) shows that our ESO risk incentive measure is a superior measure of the magnitude of managerial incentives to increase firm risk. Second, these papers treat incentives provided by ESO plans as exogenous variables rendering empirical evidence documented in these studies difficult to interpret. Third, constructing defensible measures of variance increasing investments for a cross-section of firms drawn from different industries is difficult. We avoid these design problems by relating endogenously set ESO risk incentives with an explicit measure of manager-controlled firm operating risk - exploration risk measured as the coefficient of variation of future cash flows from exploration activities - for our sample of oil and gas firms.
} 
important to accounting researchers for at least two other reasons. First, past accounting research on the value-relevance of ESO values (e.g., Aboody 1996) has had difficulty in documenting the incentive benefits of ESOs. In contrast, we show the impact of ESO risk incentives on risk-taking behavior in a relatively simple setting. Consistent with Skinner (1996), we argue that it may be premature to conclude that the incentive effects of ESOs are small or non-existent. Second, SFAS 123, Accounting for Stock-based Compensation, requires ESOs to be valued, with some small adjustments, as if they were held by outside investors incapable of influencing the ultimate value of the ESO. Our findings indicate that this premise is invalid because managers with greater ESO risk incentives appear to systematically influence risk-taking behavior of the firm so as to maximize their ESO values.

The remainder of the paper proceeds as follows. Section 2 develops our hypothesis and the conceptual model specification. Section 3 discusses sample selection, empirical design, and variable measurement. Section 4 reports the results from the empirical tests while section 5 concludes.

\section{Hypotheses development and conceptual empirical model}

As noted above, we focus on the impact on managers' risk-taking activity of the risk incentives provided by ESOs. We rely on the managerial risk aversion model drawn from the agency literature to make predictions about the association between ESO risk incentives and a manager's risk-taking actions. Throughout the discussion, we define firm risk as stock return volatility and we focus on a key action - choice of riskiness of exploration projects - that the oil and gas firm manager can take to influence this volatility.

We assume that the firm's objective is to maximize firm value and it does that, at least in part, via the choice of managerial compensation contracts. Risk-neutral shareholders would like firm managers to undertake all positive net present value projects 
(hence firm value increasing) regardless of their risk. However, risk-averse managers prefer to undertake less risky positive NPV projects, thus passing up some positive but risky NPV projects that shareholders would like undertaken ${ }^{\mathrm{B}}$ We refer to this problem as the risk-related incentive problem. As noted in the introduction, there exists a considerable body of literature recognizing that the convexity of the relation between stock price and manager's wealth, in addition to the slope of this relation, must be managed in the compensation contract to induce managers to make optimal investment and financing decisions (see Guay 1999).

In theory, ESOs offer incentives to mitigate the risk-related incentive problem as follows. The value of an ESO increases with both stock price (hereafter the ESO slope effect) and stock return volatility (hereafter the ESO risk incentive effect). The ESO slope effect offers managers incentive to undertake positive NPV projects while the ESO risk incentive effect offers managers incentive to increase stock return volatility by undertaking risky projects. Holding the ESO slope effect constant, greater convexity in the wealthperformance relation, as offered by ESOs, is expected to dampen manager's aversion toward firm risk and thus reduce the magnitude of the risk-related incentive problems associated with managers giving up positive but risky NPV projects.

In other words, because option values increase with stock return volatility, managers that have options with greater convex payoffs - greater ESO risk incentives have greater incentives to undertake actions that increase firm risk. Thus if the managerial

\footnotetext{
${ }^{3}$ One way to think of this is that risk-averse managers in evaluating project cash flows use a higher discount rate, reflecting a risk premium, than do risk-neutral shareholders. Further, it is not necessary for the riskrelated incentive problem to occur that shareholders be risk-neutral; rather, a sufficient condition is that shareholders are more diversified than managers.

${ }^{4}$ Note that compensating managers with stock, rather than ESOs, ties compensation to stock price performance but does not mitigate the risk-related incentive problem since stock compensation is linear in stock price - that is, it does not introduce any convexity into the manager's compensation function. Convexity in the compensation function is necessary to induce managers to make optimal investment decisions. Our statement that stock compensation is linear ignores the option value offered by common stock. We discuss the convexity induced by stock in greater detail later.
} 
risk aversion model is descriptive of the data and if ESOs offer effective risk incentives, we expect to observe a positive association between the riskiness of exploration projects and the magnitude of ESO risk incentives. Hence, we posit the following hypothesis (in alternate form):

H1: $\quad$ The riskiness of exploration activity is positively associated with the magnitude of ESO risk incentives.

The null hypothesis is that the riskiness of exploration activity is not associated with the magnitude of ESO risk incentives. The null is consistent with comments in the financial press and in academic work that ESOs are a politically expedient way for CEOs to pay themselves with little or no relation between ESO compensation and ex post performance (Crystal 1991, Yermack 1995, Murphy 1998).

We posit that ESO risk incentives at time $t$ are an important determinant of managerial actions in period $\mathrm{t}+1$ that are reflected in ex post exploration risk at time $\mathrm{t}+1$. Thus, we assume that exploration risk taking can be characterized in the following form: ${\text { Exploration } \text { risk }_{\mathrm{t}+1}=f(\mathrm{ESO} \text { risk incentives }}_{\mathrm{t}}$, Investment opportunity set $\mathrm{t}_{\mathrm{t}}$, Leverage $\left._{\mathrm{t}},\right)$

Investment opportunity set is included in equation (1) because we assume firms with greater investment opportunity sets are expected to undertake riskier projects compared to firms with smaller investment opportunity sets (Guay 1999). Leverage is included because Harris and Raviv (1991) and Leland (1998) argue that financial leverage creates incentives for managers to assume excessively risky projects on behalf of shareholders ex post after the debt has been sold. Hence, we expect a positive association between leverage and exploration risk.

In examining the effect of ESO risk incentives on manager's risk taking activities, both the theoretical and empirical literatures suggest that ESO risk incentives are endogenously set by the compensation committee in response to the investment opportunity set and contracting environment faced by the firm. Hemmer, Kim, and 
Verrecchia (1999), and Hirshleifer and Suh (1992) show that options help mitigate the effects of executive risk aversion by giving managers incentives to adopt rather than avoid risky projects. Smith and Watts (1992), Gaver and Gaver (1993), and Bryan, Hwang, and Lilien (2000) find that firms with greater investment opportunities use options more frequently as a part of the CEO's compensation package and Guay (1999) shows that ESO risk incentives are positively related to firms' investment opportunity sets. The intuition is that risk-related agency problems that cause managers to pass up risky, positive NPV projects are likely to be the most severe in firms with substantial investment opportunities. By providing managers with convex payoffs as in ESOs, shareholders can reduce these risk-related agency costs. In sum, prior work argues that firms vary by investment opportunity set and contracting environments and the CEO's compensation contract is set in response to these variations.

Thus to control for endogeneity of ESO risk incentives we use a system of two equations by adding equation (2) to the model:

ESO risk incentive $\mathrm{t}_{\mathrm{t}}=f\left(\right.$ Exploration risk $_{\mathrm{t}+1}$, Investment opportunity set $\mathrm{t}_{\mathrm{t}}$, CEO sensitivity of wealth to stock price , Cash balances $_{t}$, CEO risk-aversion, Firm size $_{t}$ )

Equation (1) in the two-equation system allows us to assess whether, in the crosssection, there is a positive association between the level of ESO risk incentives offered and exploration risk outcomes while also controlling for two other factors (leverage and investment opportunities) previous literature has shown to influence managers' risk-taking behavior. Equation (2) models the determinants of ESO risk incentives and is included to control for the endogeneity of ESO risk incentives in examining managers' risk-taking activities. The determinants in equation (2) are based on the analysis in Guay (1999) with a few adjustments to tailor the model to the oil and gas industry. 
Guay (1999) includes book-to-market, R\&D expenditures and investment

expenditures as proxies for the investment opportunity set in his ESO risk incentive model.

We use market-to-book and exploration costs; the latter can be thought of as a proxy for both R\&D and investment for oil and gas firms. Consistent with prior compensation research (e.g., Gaver and Gaver 1993, Baber, Janakiraman and Kang 1996, and Guay 1999), we conduct a factor analysis to statistically synthesize the two measures (market-tobook ratio and exploration costs scaled by total assets) into an empirical proxy for the investment opportunity set. The investment opportunity set (IOS) factor score captures the variation common to these two proxies in a single variable.

Firms facing an investment opportunity set with substantial exploration risk will attempt to provide managers with greater incentives to invest in riskier projects. Thus exploration risk in $\mathrm{t}+1$ can be thought of as an additional proxy for the firm's IOS. Moreover, if the $\mathrm{CEO}$ possesses private information indicating that the firm is facing a risky but highly valuable exploration project, she might attempt to influence the compensation committee to set higher ESO risk incentives. We discuss the motivation and empirical measurement of the remaining factors in the next section.

The system of equations is estimated using two-stage least squares (2SLS) procedures as it is well known that ordinary least squares (OLS) will not provide consistent estimates of the coefficients in the structural equations. However, our estimation procedure is subject to three limitations (see Holthausen et al. 1995 and Ittner and Larcker 2001).

\footnotetext{
${ }^{5}$ In their study of business unit innovation and the structure of compensation contracts, Holthausen et al. (1995) employ a similar two equation approach examining future innovation as a function of the structure of the compensation contract (proportion of total compensation tied to long-term performance), while also allowing the structure of the compensation contract to be a function of the firms' investment (innovation) opportunity set. Our approach mirrors their approach. Note that using exploration risk at time $\mathrm{t}+1$ in equation (2) as a proxy for the investment opportunity set assumes that, on average, ex post exploration risk estimated at $\mathrm{t}+1$ is a reasonable proxy for the exploration risk expected by the firm at time $\mathrm{t}$ (the date at which ESO risk incentives are determined by the compensation contract).
} 
First, only ESO risk incentive ${ }_{\mathrm{t}}$ and Exploration risk $\mathrm{t}_{\mathrm{t}+1}$ are treated as endogenous.

Other firm specific variables are assumed to be exogenous or pre-determined variables.

Obviously, identification considerations require each endogenous variable to be associated with some unique set of exogenous variables (or instruments). We acknowledge that some may view a few of the instrumental variables (e.g., exploration costs and cash balances) as endogenous choices and we would need to specify a separate equation to explain the choice of such endogenous variables. However, this would involve the difficult task of finding an exogenous variable for each such equation. Hence, our results might be affected by the possibility that a few exogenous variables in our setting may themselves be endogenous.

Second, our variables are likely measured with error, and this will produce inconsistent estimates for the structural equation parameters and their standard errors. However, without greater knowledge of the correlation structure of the measurement error, it is difficult to precisely estimate the impact of these errors on our inferences.

Third, it is quite likely that the system of equations is misspecified, because of correlated omitted variables and inappropriate zero restrictions on the coefficients between the exogenous instruments and the endogenous variables. For example, the extent of exploration risk taken is possibly chosen in response to factors other than ESO risk incentives and leverage. To the extent our analyses do not consider all the determinants of exploration risk taking or ESO risk incentives, we face the possibility that our results are affected by unidentified omitted variable problems.

\section{Sample, Variable Measurement, and Descriptive Statistics}

In this section, we describe our sample selection process, empirical model variable measurement, and present descriptive statistics. Our data come from four sources. We obtain data on CEO option and stockholdings from Standard and Poor's Execucomp 
database. This database contains compensation data, beginning in 1992, for the top five executives of over fifteen hundred U.S. publicly traded corporations. CRSP data are used to generate measures of stock-return volatility and treasury bond yields. Data on exploration activity and hedging activity (discussed in section 4.2) are hand-collected from firms' annual reports and 10-Ks. We use Compustat as the source of firms' accounting data.

\subsection{Sample}

We obtain a sample of oil and gas CEOs from the 1998 S\&P Execucomp database. Restricting attention to oil and gas CEOs for the period 1992 to 1997 , we begin with a sample of 160 CEO-year observations. We do not consider stock option data for 1998 because exploration risk information for the following year, 1999, was not available at the time the paper was first drafted (recall that we relate exploration risk for year $t+1$ with the ESO risk incentives computed at the end of year $\mathrm{t}$ ). We eliminate $11 \mathrm{CEO}$-years with missing option portfolio data and 23 and 5 observations due to missing $10-\mathrm{Ks}$ and missing data to compute exploration risk measures, respectively. As reported in panel A of Table 1, this results in 121 observations with complete data on CEO option compensation and oil and gas data.

Panel B of Table 1 provides descriptive statistics on the sample firms. The median firm has \$234.95 million in sales and \$676.61 million in total assets and \$690.52 million in market value of equity. The return on total assets for the median firm is $3.44 \%$. Panel $\mathrm{C}$ presents descriptive data for CEO compensation. The median CEO receives $\$ 349.12$ thousand in salary, $\$ 135.39$ thousand as bonus and $\$ 324.65$ thousand (Black-Scholes value) in new option grants per year. Thus option compensation represents a substantial portion of the annual compensation paid to a typical CEO in the sample. 


\subsection{Empirical model}

Based on the conceptual models in equations (1) and (2), the empirically estimated system of equations is as follows (firm subscripts suppressed for expositional convenience):

$$
\begin{array}{r}
\text { Exploration risk }_{\mathrm{t}+1}=\gamma_{0}+\gamma_{1} \text { ESO risk incentives }_{\mathrm{t}}+\gamma_{2} \text { Leverage }_{\mathrm{t}}+ \\
\gamma_{3} \text { IOS factor score } \\
\mathrm{t}
\end{array}
$$

ESO risk incentives $\mathrm{t}_{\mathrm{t}}=\beta_{0}+\beta_{1}$ Exploration risk $_{\mathrm{t}+1}+\beta_{2}$ IOS factor score $\mathrm{t}_{\mathrm{t}}+\beta_{3} \log (\text { assets })_{\mathrm{t}}+$ $\beta_{4}$ Sensitivity of wealth to stock price ${ }_{t}+\beta_{5}$ Cash compensation $_{t}+\beta_{6}$ Cash balances $_{t}+$ error $_{t}$

Recall equation (4) is included to allow for the endogeneity of ESO risk incentives in testing our hypothesis that the riskiness of exploration activity is positively associated with ESO risk incentives - that is, the hypothesis predicts that $\gamma_{1}>0$. Our model of ESO risk incentives is based on Guay's (1999) model estimated across a broad cross-section of firms. We have already discussed the inclusion of the IOS factor score and exploration risk as proxies for the firm's investment opportunity set.

Smith and Watts (1992) argue that larger firms will likely pay greater compensation to their executives. Because ESO values are an important component of total management compensation, and ESO risk incentives are likely to be positively correlated with ESO values, we control for a possible positive relation between ESO risk incentives and firm size by including $\log ($ assets $)$.

Though ESOs add convexity to the relation between manager's wealth and stock price, ESOs also increase the slope of this relation. Smith and Watts (1992) argue that firms with greater investment opportunities tie a manager's wealth more closely to firm performance. To control for a relation between the wealth-performance slope and

\footnotetext{
${ }^{6}$ Execucomp assigns a code of 4060 to this industry while Compustat uses the more standard SIC code of 1311. The firms we extract using Execucomp's code 4060 are listed as SIC 1311 on Compustat.

${ }^{7}$ The correlation between ESO risk incentives and the Black-Scholes value of the CEO's options for our sample is $0.74(\mathrm{p}=0.00)$.
} 
investment opportunities, we follow Guay (1999) and add the sensitivity of the CEO's firm-specific wealth to stock price in regression (4).

The incentives offered by ESOs to increase firm risk are likely to depend on CEO's risk aversion, or the reduction in the utility that risk-averse, poorly diversified managers experience when the volatility of their wealth increases. However, empirical data on managerial risk-aversion are not available. An advantage of examining risk-taking actions in a specific industry such as oil and gas is that executives with similar risk preferences or utility functions would self-select to work in the same industry (see Lambert et al. 1991). Therefore, risk-preferences or utility functions of CEOs within an industry are likely to display less inter-firm variation as compared to a study that includes a broad cross section of firms. Nevertheless, we attempt to explicitly control for inter-firm differences in potential CEO risk-aversion by including CEO's cash compensation as an explanatory variable. Following Guay (1999), we argue that the greater the cash compensation that can be invested outside the firm, the better diversified the CEO is likely to be, and the lower her expected risk-aversion. Hence, the compensation committee needs to give a more diversified CEO lower ESO risk incentives as compared to a less diversified CEO to take the same level of firm risk. This argument predicts a negative relation between ESO risk incentives and cash compensation. Another argument predicting a negative relation between ESO risk incentives and cash compensation stems from the positive correlation between ESO risk incentives and a CEO's option values. If more ESO risk incentives imply greater option values and if CEOs in the oil and gas industry are compensated equally after controlling for size, then cash compensation will be lower for firms with greater option values. However, it is also possible that if firms wish to set higher ESO risk

\footnotetext{
${ }^{8}$ Constraining ESO risk incentives to depend on the sensitivity of CEO wealth to stock price recognizes that infinite increases in risk taking behavior are not likely to be optimal as a project with infinite risk may not
} 
incentives for their CEOs with no corresponding increase in compensation, the CEOs may seek employment elsewhere. If firms pay a risk premium in the form of cash compensation, we would expect a positive relation between ESO risk incentives and cash compensation. Thus, cash compensation could exhibit a positive or a negative relation with ESO risk incentives.

Finally, we add a cash balance variable to the Guay model. Yermack (1995) and Dechow et al. (1996) argue that liquidity constraints can induce firms to use stock options in lieu of cash compensation resulting in a negative relation between the value of options given and cash balances (our proxy for liquidity constraints). As ESO risk incentives are likely to be positively correlated with stock option values, we control for a potential negative relation between ESO risk incentives and cash balances. ${ }^{0}$

\subsection{Measurement of key variables}

\subsection{Exploration risk (ExpRisk)}

We measure exploration risk as the coefficient of variation $(\mathrm{CV})$ in estimated discounted future operating cash flows from exploration activities undertaken in period $t+1$. Specifically, we compute exploration risk (ExpRisk) as the variance of expected future operating cash flows from exploration activity undertaken in year $\mathrm{t}+1$ scaled by the mean of expected future cash flows from exploration activity undertaken in year $t+1$. The mean and variance are calculated from the end of period $\mathrm{t}+1$ disclosures about exploration

remain a positive NPV project. We assume that compensation committees are likely to provide ESOs to encourage assumption of risky but positive NPV projects.

${ }^{9}$ Guay (1999) also included CEO age and the logged version of sensitivity of wealth to stock price as additional proxies for CEO risk aversion in his model of ESO risk incentives. We omit the age variable here because it was not significant in his model. We introduced a logged version of the sensitivity of wealth to stock price (besides the sensitivity of wealth to stock price) in our model and found that the logged version was statistically insignificant in all specifications.

${ }^{10}$ The coefficient of variation in cash flows from exploration activity avoids shortcomings associated with other plausible measures of exploration risk. Exploration costs are not used as a proxy for exploration risk because the success or failure of exploration activity may not be related to exploration costs (see para 55, SFAS 69). However, in the spirit of Guay (1999), exploration costs is used as a proxy for the firm's investment opportunity set in the ESO risk incentive regression (4). Drilling success rate $(\theta)$ and the number 
activity during period $\mathrm{t}+1$. The $\mathrm{CV}$ from reserve discovery activity undertaken during year $\mathrm{t}+1$ is treated as an ex post measure of the exploration risk that managers take in response to ESO risk incentives at the end of year $\mathrm{t}$.

The proxy for exploration risk is based on the analysis by Sunder (1976). Sunder models the number of successful wells drilled in any period t as a random variable that follows a binomial distribution with parameters $\mathrm{N}$ and $\theta$, where $\mathrm{N}$ refers to the number of exploratory wells drilled during a period and $\theta$ represents the probability of finding a successful wet exploratory well. He shows that the variance of net operating cash flows for $\mathrm{L}$ years in the future for a steady-state firm is:

$$
\text { Variance }=\mathrm{x}^{2} \mathrm{~L} \mathrm{~N} \theta(1-\theta)
$$

where $\mathrm{x}$ is the discount factor adjusted net operating cash flow per successful exploratory well per period for $\mathrm{L}$ periods; $\mathrm{L}$ is the average lifetime of a successful well; $\mathrm{N}$ is the number of exploratory wells drilled in the period; and $\theta$ is the probability that an exploratory well will result in the discovery of exploitable reserves.

The mean of the future cash flows from discoveries is given by:

$$
\mathrm{Mean}=\mathrm{x} \mathrm{L} \mathrm{N} \theta-\mathrm{Nc}
$$

where $\mathrm{c}$ is the exploration cost per well.

The theoretical derivation of (5) and (6) can be found in Sunder (1976). It is important to recognize that the mean and the variance of cash flows are not affected by the method of accounting for exploration costs, successful efforts or full cost, because the measure uses cash flows and not accounting income.

ExpRisk is computed for every firm-year in the sample using SFAS 69 disclosures of a firm's annual reserve activity. The appendix illustrates how a single years' SFAS 69 disclosures are used to compute the ExpRisk measure for the sample firm, Newfield 
Exploration Company, for the year 1995. Note that the ExpRisk measure derived from 1995 year-end disclosures is matched to ESO risk incentives of Newfield's CEO computed as of 1994 year-end in the regression analysis.

There are two advantages to computing ExpRisk using the above-mentioned approach. First, Sunder's model of the drilling process enables us to derive the mean and variance of exploration related future cash flows using a single year's disclosures of estimated future cash flows from that year's discovery activity as per SFAS 69. In contrast, cash flows attributable to specific risk-taking actions are not generally observable for a sample of industrial firms. Even if such cash flows were observable, estimating volatility from time-series observations of cash flows is fraught with difficulties associated with either missing or overlapping observations and the stickiness of volatility measures that such overlapping observations induce. Second, we can make valid cross-sectional comparisons of ExpRisk measures across firms because firms are required to report future cash flows from discoveries based on the parameters laid down by the FASB in SFAS 69. Note however we recognize that firms do not explicitly disclose exploration risk measures and hence our exploration risk proxy could be measured with error. For example, because SFAS 69 measures focus only on proven reserves, some of current period exploration activity may result in the discoveries of unproven reserves that may be reclassified as proven reserves in later periods. Such measurement error could dampen the statistical associations between ExpRisk and our test variable, ESO risk incentives. However, the impact of such measurement error on the 2SLS coefficients is difficult to predict.

Panel A of Table 2 presents descriptive data on ExpRisk and its individual components. The median sample firm explores 11.3 wells $(\mathrm{N})$ in a year and has a success rate $(\theta)$ of 0.5 . The productive life of a successful well for the median firm is 8.74 years 
and each successful well yields $\$ 2.45$ million cash flow for every year of its productive

life. For the median firm, the mean and variance of estimated future cash flows are $\$ 97$

million and $\$ 165.86$ million, respectively. The coefficient of variation from exploration

(ExpRisk) for the median firm (mean) is 1.59 (3.45).

\subsection{Measurement of ESO risk incentives}

ESO risk incentives is our measure of the incentives offered to managers to alter the variance of the firm's stock returns. Following Guay (1999), we measure ESO risk incentives as the sensitivity of the CEO's option portfolio value to a $1 \%$ change in the underlying stock return volatility. ${ }^{11}$ For a given option, we estimate ESO risk incentives as the change in the value of the option for a small change $(0.01)$ in the underlying stock return variance. We use the dividend-adjusted Black-Scholes model to estimate the value of the option: $\frac{12}{12}$

$$
\mathrm{w}=\mathrm{S} \mathrm{e}^{-\delta \mathrm{T}} \mathrm{N}\left(\mathrm{d}_{1}\right)-X \mathrm{e}^{-\mathrm{rT}} \mathrm{N}\left(\mathrm{d}_{2}\right)
$$

where $\mathrm{w}$ is the Black-Scholes value of a European call option as modified to account for dividends by Merton (1973); $\mathrm{S}$ is the price of the underlying stock at the valuation date; $\delta$

\footnotetext{
${ }^{11}$ As noted earlier, equity can be viewed as a call option on the firms' assets and might be important for manager's risk incentives especially in financially distressed firms (because the call option is close to the money). Our reported tests ignore convexity that stems from CEO-owned equity understating our risk incentive measure if the firm is financially distressed and biases against finding any predicted relations. Note however that we are able to document relations between ESO risk incentives (convexity) and exploration risk, ignoring any ownership related convexity. In addition, we omit in turn sample firms that are in the lowest quartile of the quick ratio distribution and firms with negative earnings (on the assumption that these firms, if any, might exhibit financial distress) and re-estimate our system of equations (3) and (4). The results from such analyses are qualitatively similar to those reported in the main results section of the paper. ${ }^{12}$ It is well known that the assumptions underlying the Black-Scholes model are not fully descriptive when applied to ESOs (for example, risk averse managers exercise their ESOs before maturity). However, following and for comparability with Core and Guay $(1998,1999)$ and Guay $(1999)$ we rely on the BlackScholes model while recognizing that this likely introduces measurement error into our ESO risk incentives measure. Examination of the partial derivative in equation (8) suggests the partial derivative based on the BS model likely overstates the derivative and hence ESO risk incentives. Given ESO risk incentives are likely overstated, one might conjecture that the association between ESO risk incentives and exploration risk is downward biased (understated) - that is, the estimate of $\gamma_{1}$ in equation (3) is downward biased. However, we use 2SLS to estimate our system of equations, which is a special case of instrumental variables, and the instrumental variables technique is also a common approach to mitigate measurement error in explanatory variables. The extent to which the instrumental variables procedure mitigates measurement error in the ESO risk incentives measure is unknown. Thus, it is difficult to predict the econometric consequences for our hypothesis test in equation (3).
} 
is expected annual dividend rate over the life of the option; $\mathrm{T}$ is time to maturity of the option in years; $\mathrm{N}$ is cumulative probability function for the normal distribution; $\mathrm{X}$ is the exercise price of the option; $r$ is annual risk free interest rate; $d_{1}$ is $\left[\ln (S / X)+\left(r-\delta+\sigma^{2} / 2\right) T\right] /$ $\sigma \mathrm{T}^{1 / 2} ; \sigma$ is the expected annual stock return volatility over the life of the option, and $\mathrm{d}_{2}$ is $\mathrm{d}_{1}$ $-\sigma T^{1 / 2}$

Thus we estimate the sensitivity of the change in option value to a $1 \%$ change in stock return volatility as

$$
[\partial \mathrm{w} / \partial \sigma] * 0.01=\mathrm{e}^{-\delta \mathrm{T}} \mathrm{N}^{\prime}\left(\mathrm{d}_{1}\right) \mathrm{S} \mathrm{T}^{1 / 2} * 0.01
$$

where $\mathrm{N}^{\prime}$ is the normal density function.

The ESO risk incentives of the current year's grant can be computed using the number of options, exercise price, and time to maturity from Execucomp for the most recent year's grant (hereafter labeled new grants). However, for previously granted options, data on each series of grants are not readily available. Hence, we use the Core and Guay $(1998,1999)$ one-year approximation method to estimate ESO risk incentives for previously granted options. This method is convenient in that it requires information only from the most recent proxy statement. The algorithm uses the three ESO series reported by Execucomp - new grants, unexercisable, and exercisable..$^{13}$ We estimate equation (8) for an option in each of the three series and then multiply by the number of ESOs held by the CEO within each series and aggregate across the three sums to derive the total dollar measure of ESO risk incentives. Thus the greater the number of options held, ceteris paribus, the larger the ESO risk incentives. Core and Guay (1998) show that their method yields estimates of ESO risk incentives that are both unbiased and highly correlated (more than $95 \%$ ) with the measures that would be obtained if the parameters of each set of prior grants in the CEO's option portfolio were known. 
We focus on the CEO for three reasons. First, the CEO assumes overall responsibility for the firm's operations and decisions about the extent of operating risk are most likely made at this level. Second, CEO's stock option data are easily accessible from Execucomp. Third, since most prior studies have focused on CEO compensation, we can compare our results with theirs. Furthermore, CEO (as opposed to other executives) pay is most often the subject of debate among various stakeholders in the firm such as organized labor and institutional owners (see Murphy 1998).

Panel B of Table 2 provides descriptive data on ESO risk incentives and some of its components. The mean change in the value of CEO options portfolio for a $1 \%$ change in stock return variance is $\$ 30.97$ thousand with a standard deviation of $\$ 41.48$ thousand. Thus, there appears to be reasonable cross-sectional variation in the ESO risk incentives measure and hence in the options' incentive effects. The median ESO risk incentives in our sample (\$17.66 thousand) are somewhat smaller than the median risk incentive for a broad cross-section of industries ( $\$ 28.47$ thousand) reported by Core and Guay (1998).

We find that the median change in the value of a CEO's stock (both common and restricted stock holdings) and options for a $1 \%$ change in stock value is $\$ 89.15$ thousand. Guay (1999) reports a median change of $\$ 90.68$ thousand for a $1 \%$ change in stock value for a set of randomly chosen firms. The median CEO's stock-based wealth in the firm is $\$ 5.83$ million. Guay (1999) reports that the median CEO’s stock-based wealth for his random sample of firms is $\$ 6.79$ million. Turning to the other variables reported in panel $\mathrm{C}$ of Table 2, note that the median firm has a book-to-market (BM) ratio of 0.41 and its long-term debt is about half of its market value of equity. ${ }^{14}$ An average firm's exploration costs are approximately $4 \%$ of its total assets. Although the IOS factor score has a zero

\footnotetext{
${ }^{13}$ It is important to note that Execucomp includes new grants in the totals for unexercisable and exercisable (if new grants vest quickly). Thus, we adjust the unexercised and exercisable totals to reflect new grants.
} 
mean by construction, variation around the mean captures variation in firms' investment opportunities. A higher IOS factor score indicates a larger IOS.

\subsection{Evidence on the importance of exploration risk on CEO's wealth}

A maintained assumption in our analysis is that ESOs offer sufficient incentives for managers to change exploration activities. This assumption also implies that exploration risk is an important risk faced by oil and gas firms. We estimate the following regression to provide evidence on both issues (firm subscripts suppressed for convenience):

$$
\begin{gathered}
\sigma_{\mathrm{t}}=\theta_{0}+\theta_{1} \text { ExpRisk }_{\mathrm{t}}+\theta_{2} \delta_{\text {oilt }}+\theta_{3} \mathrm{BM}_{\mathrm{t}}+\theta_{4} \text { Leverage }_{\mathrm{t}}+\theta_{5} \log \left(\text { total assets }_{\mathrm{t}}\right) \\
+ \text { year dummies }+\mathrm{v}_{\mathrm{t}}
\end{gathered}
$$

where $\sigma_{\mathrm{t}}$ is the annual standard deviation of daily stock returns and oil price exposure $\left(\delta_{\text {oilt }}\right)$, book-to-market ratio, leverage, and total assets are included as controls. Oil price exposure $\left(\delta_{\text {oilt }}\right)$ is introduced because it is likely to be an important risk factor for oil and gas firms (see Rajgopal 1999). Oil price exposure is measured for each firm $\mathrm{j}$ in year $\mathrm{t}$ from the following extended market model using daily stock returns $\left(\mathrm{R}_{\mathrm{jt}}\right)$, daily marketindex returns $\left(\mathrm{MKTRET}_{\mathrm{t}}\right)$ and daily percentage change in West Texas Intermediate grade of oil $\left(\Delta \% \mathrm{OPRICE}_{\mathrm{jt}}\right): \mathrm{R}_{\mathrm{jt}}=\delta_{0 \mathrm{jt}}+\delta_{\mathrm{mktj}} \mathrm{MKTRET}_{\mathrm{t}}+\delta_{\mathrm{oiljt}} \Delta \% \mathrm{OPRICE}_{\mathrm{t}}+\varepsilon_{\mathrm{jt}}$

The results of the regression are reported in Table 3. Exploration risk is significantly positively associated with stock return volatility and the model explains $33 \%$ of the cross-sectional variation in stock-return volatility. The estimated regression coefficients can be used to estimate the wealth effects to CEOs of changing exploration risk. An increase of one standard deviation in ExpRisk of 5.87 units is estimated to increase stock return volatility by 2.93 percentage points $(.005 \times 5.87=2.93 \%) . \frac{15}{}$ This

\footnotetext{
${ }^{14} \mathrm{We}$ found 3 firm-years with negative book to market ratios. The tenor of the inferences was unchanged when these 3 firm-years were deleted from the sample.

${ }^{15}$ By way of benchmarking the magnitude of the estimated coefficient, $\theta_{1}=.005$, a one standard deviation increase in oil price beta of .135 is estimated to increase stock return volatility by $2.56 \%(.19 \times .135=$ $2.56 \%)$.
} 
translates to a $\$ 90.80$ thousand ( $\$ 51.83$ thousand) increase in ESO values for the mean

(median) sample firm.

To assess the feasibility of a one standard deviation increase of 5.87 in ExpRisk, we compute the required change in one of the components of ExpRisk when other components are set to the sample means. A $110 \%$ increase in the average cash flows per successful well (denoted $x$ in the model), would increase ExpRisk by 5.87 .7 To assess the likelihood of a $110 \%$ increase in the average cash flows per successful well, we find that the $\mathrm{CEO}$ of the mean firm in our sample could have increased cash flow per well over $600 \%$ implying an increase of $\$ 495,272(6 / 1.1 * \$ 90,800)$ in her option values. 18

Furthermore, expressing the sensitivity of ESO risk incentives in terms of one standard deviation of ExpRisk does not fully capture the increase in mean expected cash flows and hence CEO's wealth from assuming risky projects. Note that the mean (median) expected value of discoveries is a sizeable \$176.16 million (\$97 million). Undertaking risky exploration activities would be accompanied by increases in expected cash flows and such increases would be reflected in the CEO's wealth via ESO slope and stock slope. Exactly what portion of the increases in expected cash flows is on account of ESO risk incentives is difficult to quantify. Hence, focus on ESO risk incentives ignores the ESO slope impact of taking risky exploration projects and likely understates the economic impact of increasing exploration risk on the CEO's wealth.

\footnotetext{
${ }^{16}$ Recall, a $1 \%$ increase in stock return volatility increases ESO value for the mean (median) firm manager by $\$ 30.97$ thousand ( $\$ 17.66$ thousand). Thus multiplying by 2.93 results in a mean (median) increase of $\$ 90.8$ thousand ( $\$ 51.83$ thousand) increase for the mean (median) sample firm.

${ }^{17}$ Note that several variables such as N, number of wells; L, well age; and $\theta$, the drilling success rate, affect both the variance and mean cash flows from exploration risk to roughly the same extent. Hence ExpRisk, which is the variance scaled by the mean future cash flows, is relatively insensitive to changes in any one of these variables when the other variables are set to their sample means.

${ }^{18}$ In particular, we computed the ratio of the annual highest to the annual lowest average cash flows per successful well for each sample firm. The mean of such a ratio across firms is 7.33 and the median is 4.47 . Given that a $110 \%$ increase in cash flows increases CEO option value by $\$ 90,800$, option values for our mean sample firm's CEO could have potentially increased by $\$ 605,058$ i.e., $(7.33 / 1.10) * 90,800$ and for the median firm by $\$ 368,978$ i.e., $(4.47 / 1.10) * 90,800$. Thus, the potential increases in managerial wealth are not meager.
} 


\section{Results and specification checks}

\subsection{Main results}

Results from the two-stage least squares estimation of equations (3) and (4) are presented in Table 4. Column A of Table 4 reports the results for the exploration risk equation (3). Consistent with $\mathrm{H} 1$, we find a significant positive association between ESO risk incentives and the level of ex post exploration risk taken by the firm. The estimated coefficient on leverage is positive and significant, consistent with the claim that highly levered firms appear to take on greater exploration risk. The estimated coefficient on the IOS factor score is positive and significant consistent with the claim that firms with greater investment opportunities appear to take on higher exploration risk. The regression model explains a reasonable amount of cross-sectional variation, as evidenced by the adjusted Rsquare of $10.35 \%$.

For the ESO risk incentive equation (4) reported in column B of Table 4, there is no

evidence that exploration risk at time $\mathrm{t}+1$ has a positive relation with ESO risk incentives. 19 This null result is consistent with two interpretations - exploration risk in period $\mathrm{t}+1$, an $e x$ post measure, is a poor proxy for ex ante riskiness of the IOS set, and/or firms do not consider riskiness of the IOS in determining the CEO's ESO risk incentives. ESO risk incentives exhibits a positive but weakly significant association with IOS factor score consistent with the claim that firms with larger investment opportunity sets give their CEOs greater incentives to take risk.

ESO risk incentives exhibit a positive association with the sensitivity of CEO's wealth to stock price. We also find a strong positive association between cash compensation and ESO risk incentive suggesting that firms pay CEOs greater cash 
compensation if they impose more risk on them via ESO risk incentives. The adjusted R-

square for the regression model is reasonable at $32.18 \%$.

Overall the results are consistent with managers appearing to take on riskier exploration projects aimed at increasing firm risk in response to ESO risk incentives.

These findings imply that if the exogenous determinants of ESO risk incentives changed so as to cause ESO risk incentives to increase, we should expect to observe an increase in subsequent exploration risk taking, holding the other determinants of exploration risk constant.

\subsection{Additional tests: The effect of ESO risk incentives on oil price hedging}

Another potentially important risk that CEOs of oil and gas firms have to manage is the firm's exposure to oil price risk. Table 3 reports results indicating that oil price risk is positively related to stock return volatility $\left(\theta_{2}>0\right)$. One way to manage price risk is via hedging. Smith and Stulz (1985) and Tufano (1996) suggest that ESOs reduce incentives for managers to hedge price risk because ESOs increase in value with stock price volatility. ${ }^{0}$ Hence, we would expect to observe a negative association between ESO risk incentives and the extent of hedging.

\footnotetext{
${ }^{19}$ We conducted Hausman (1978) tests to determine whether ExpRisk E $_{\mathrm{t}+1}$ and ESO risk incentives are $_{\mathrm{t}}$ endogenous variables. The tests suggest that ExpRisk ${ }_{t+1}$ is not endogenous in the ESO risk incentives $s_{t}$

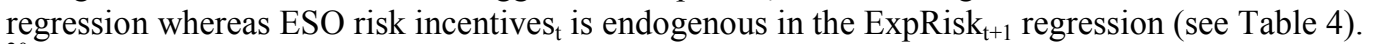

${ }^{20}$ As noted by Smith and Stulz (1985), hedging is a value-maximizing activity if it reduces the costs of market imperfections. ESO slope (and stock slope) offer incentives to managers to hedge more while the ESO risk incentive offers incentives to hedge less. We assume that we have captured the potential firm value and hence $\mathrm{CEO}$-wealth maximizing incentives from hedging by endogenizing ESO risk incentives as a function of the CEO's sensitivity of equity and options to stock price. To the extent this assumption is incorrect and ESO risk and ESO slope are positively correlated, it is possible that we might observe no or even a positive association between hedging and ESO risk incentives.

${ }^{21}$ We have chosen to present the hedging analysis merely as an additional test for the three reasons: (1) Our limited sample prevents us from specifying three equations where exploration risk, hedging and ESO risk incentives are simultaneously modeled; (2) Our small sample drawn from the oil and gas industry offers particular advantages with respect to measuring exploration risk and not as much for "price risk" especially because we cannot comprehensively examine price risk management decisions other than hedging (such as storage policies, contracting etc); (3) We believe our study makes a bigger contribution to the compensation literature relative to the financial risk management literature.
} 
To test this expectation we estimate the following system of equations using 2SLS where Hedge ratio (in lieu of exploration risk) and ESO risk incentives are treated as endogenous variables in the system:

Hedge ratio ${ }_{\mathrm{t}}=\delta_{0}+\delta_{1}$ ESO risk incentives ${ }_{\mathrm{t}}+\delta_{2}$ IOS factor score I $_{\mathrm{t}}+\delta_{3} \log (\text { assets })_{\mathrm{t}}+$ $\delta_{4}$ Leverage $_{\mathrm{t}}+\delta_{5}$ Divpayout $_{\mathrm{t}}+\delta_{6}$ Quickratio $_{\mathrm{t}}+\delta_{7}$ O\&G Sales $\%_{\mathrm{t}}+$ error $_{\mathrm{t}}$

ESO risk incentives ${ }_{\mathrm{t}}=\beta_{0}+\beta_{1}$ Hedge ratio $_{\mathrm{t}}+\beta_{2}$ IOS factor score IO $_{\mathrm{t}}+\beta_{3} \log \left(\right.$ assets $_{\mathrm{t}}+$ $\beta_{4}$ Sensitivity of wealth to stock price $t_{t}+\beta_{5}$ Cash compensation $_{t}+\beta_{6}$ Cash balances $_{t}+$ error $_{t}$

In equation (10) Hedge ratio ${ }_{t}$ is the quantity of reserves hedged scaled by the quantity of proven reserves held by the firm at year-end t (see Rajgopal 1999 for an example of the computation and the limitations of the measure); Divpayout $t_{t}$ is the dividends paid scaled by earnings before extraordinary items in year $t$; Quick ratio $t$ is the ratio of cash and short-term investments at the end of year $t$ divided by current liabilities at the end of year $t$; O\&G Sales $\% t$ is the percentage of the firm's sales in year $t$ that are attributable to sale of oil and gas. Other variables have been defined earlier. 22

We predict a positive relation between hedge ratio and IOS factor score as hedging is expected to mitigate an unexpected reduction in internally generated cash flows and hence can be of greatest benefit to firms that need internal cash flows to finance investment opportunities (see Froot et al. 1993 and Smith and Stulz 1985). Because prior empirical evidence (e.g., Nance et al. 1993 and Mian 1996) indicates that large firms hedge more than small firms, we include $\log (\text { assets })_{\mathrm{t}}$ as an instrument.

We introduce leverage because previous research (Smith and Stulz 1985 and Geczy et al. 1997) argues that exogenous bankruptcy costs create incentives for bondholders to support optimal hedging. Hence, we expect a positive association between leverage and exploration risk. Froot et al. (1993) argue that hedging reduces a firm's dependence on

\footnotetext{
${ }^{22}$ To conserve space we do not table descriptive statistics for the new variables in the hedge ratio analysis. However, the mean of each of the new variables is as follows: hedge ratio $3 \%$, dividend payout $22 \%$, quick ratio $45 \%$, and O\&G Sales $\% 86 \%$.
} 
external financing. Hence, we expect a negative association between hedging and both the availability of internal funds and short-term liquidity. We use two proxies to measure liquidity constraints - the quick ratio (see Gezcy et al. 1997) and the dividend payout ratio (Sharpe and Nguyen 1995, Fazzari et al. 1988, Kaplan and Zingales 1997, Fazzari, et al. 2000, Kaplan and Zingales 2000, and Haushalter 2000). The greater the firm's quick ratio, the lower its need to hedge to reduce expected financial distress and agency costs of debt. Assuming firms that face liquidity constraints do not pay dividends, we expect the dividend payout ratio to be negatively related to hedge ratio.

Finally, we include the percentage of a firm's sales that come from oil and gas (O\&G Sales percent) as a proxy for the extent of diversification. The higher the percentage of sales arising from oil and gas activities, the greater the reliance on oil and gas activities, and the more exposed the firm is to oil price changes. Assuming that the firm's sales from non-oil and gas production relate to activities whose cash flows are negatively correlated or uncorrelated with oil and gas prices, we predict a positive association between O\&G Sales percent (as a proxy for diversification) and hedging.

Results from estimating the hedge ratio equation (model 10) and ESO risk incentive equation (model 11) using 2SLS are shown in columns A and B of Table 5. Consistent with the findings related to exploration risk, we observe a significant negative association between the extent of oil price hedging and ESO risk incentives (see column A). However, the compensation committee does not appear to consider the extent of price risk hedging while setting ESO risk incentive levels (see column B). Results related to other variables in the ESO risk incentive regression are similar to those reported earlier in Table 4. In the hedge ratio regression, we find that larger firms and firms with greater investment opportunity sets hedge more while firms with higher quick ratio and hence fewer liquidity constraints hedge less. The other control variables are not significant. 


\subsection{Are hedging and exploration risk decisions taken simultaneously?}

We also considered the possibility that hedge ratio at time $t$ might influence the extent of exploration risk taken during year $t+1$ and thereby affect the main results reported

in sections 4.1 and 4.2. However, the Spearman correlation between ExpRisk $\mathrm{t}_{\mathrm{t}+1}$ and Hedge ratio $\mathrm{t}_{\mathrm{t}}$ is not statistically significant $(0.04, \mathrm{p}=0.59)$. Furthermore, when Hedge ratio $_{t}$ is added as an explanatory variable in the exploration risk regression (equation 3 ), the coefficient on hedge ratio is not statistically significant $(p=0.84$, two tailed, results untabulated). Analogously, the coefficient on ExpRisk $\mathrm{t}_{\mathrm{t}+1}$ is not significant when that variable is introduced as a regressor in the hedge ratio regression, equation $10(\mathrm{p}=0.63$, two-tailed, results untabulated). Hence, we do not find evidence to indicate that the Hedge ratio $_{\mathrm{t}}$ and ExpRisk $\mathrm{E}_{\mathrm{t}+1}$ are simultaneously determined.

\section{Conclusions}

We present some of the first evidence of a direct link between the magnitude of incentives provided to CEOs by ESOs to increase firm risk and explicit ex post managerial actions designed to increase firm risk. Because of the availability of accounting disclosures to measure exploration risk we focus on a sample of oil and gas firms and investigate the impact of ESOs on the level of exploration risk assumed. We use Sunder's (1976) theoretical model to guide the measurement of exploration risk using SFAS 69 data for a single period. We operationalize exploration risk as the coefficient of variation in estimated future cash flows from exploration activity conducted during the year following the date on which the ESO risk incentive is measured. We measure the incentives given by ESOs to increase firm risk as the sensitivity of the CEO's ESO portfolio to equity return volatility.

We find that the coefficient of variation of future cash flows from exploration activity (exploration risk) exhibits a positive association with the sensitivity of ESOs to 
stock return volatility for our sample firms. This result obtains after controlling for the endogenous determination of ESO risk incentives and exploration risk taking. However, the ex ante investment opportunity set, not ex post exploration risk, appears to be a factor that determines ESO risk incentive setting. In a different research setting, Holthausen et al. (1995) also find that ex post measures of innovation are not related to long-term compensation, although long-term compensation is positively related to future innovation.

Additional tests reveal that ESO sensitivity to stock return volatility is associated with less hedging of oil and gas price risk exposure again after accounting for the endogeneity of ESO risk incentives and hedging. In sum, our findings are consistent with the hypothesis that ESOs reduce managerial incentive problems by motivating them to invest in risky projects. An important caveat is that our study considers a small sample within a single industry. Future work could assess the robustness of our findings if reasonable measures of operating risk can be found for a broader cross-section of firms and industries. Evaluation of the shareholder wealth implications of the relations between ESO risk incentives and risk-taking actions is also a fruitful area of future research. One step towards such evaluation is to understand whether ESO risk incentives are set by new option grants in a manner consistent with firm-value maximization. This analysis would extend Core and Guay (1999) who examine whether ESO slope incentives of new option grants are set in a manner consistent with firm-value maximization. Note, however, that because we model (endogenize) ESO risk incentives and find a positive association between exploration risk and ESO risk incentives, our results are consistent with the idea that giving ESO risk incentives is a firm value, as well as CEO wealth, maximizing strategy. 


\section{References}

Aboody, D. 1996. Market Valuation of Employee Stock Options. Journal of Accounting and Economics 22: 357-91.

Agrawal, A. and G. Mandelker. 1987. Managerial Incentives and Corporate Investment and Financing Decisions. Journal of Finance 42: 823-37.

Alciatore, M. 1993. New Evidence on SFAS No. 69 and the Components of the Change in Reserve Value. The Accounting Review 68: 639-656.

Baber,W., S. Janakiraman, and S. Kang. 1996. Investment Opportunities and the Structure of Executive Compensation. Journal of Accounting and Economics 21: 297-318.

Barth, M.E. 1998. Cited in Risk and Financial Reporting: A Summary of the Discussion at the 1997 AAA/FASB Conference. Accounting Horizons 12(3): 271-82.

Bryan, S., L. Hwang, and S. Lilien. 2000. CEO Stock-Based Compensation: An Empirical Analysis of Incentive-Intensity, Relative Mix, and Economic Determinants. Journal of Business 73: 661-693.

Core, J. and W. Guay. 1998. Estimating the Incentive Effects of Executive Stock Option Portfolios. Working Paper, November, University of Pennsylvania, Philadelphia, PA.

Core, J. and W. Guay. 1999. The Use of Equity Grants to Manage Optimal Equity Incentive Levels. Journal of Accounting and Economics 28: 151-184.

Copeland, T., and J.Weston. 1988. Financial Theory and Corporate Policy. AddisonWesley Publishing Co. Reading, MA.

Crystal, G. 1991. In Search of Excess: The Overcompensation of American Executives, W.W. Norton \& Company: New York.

Dechow, P., A. Hutton, and R. Sloan. 1996. Economic Consequences of Accounting for Stock Option Compensation. Journal of Accounting Research 34 (Suppl.): 1-20.

Defusco, R., R. Johnson, and T. Zorn. 1990. The Effect of Executive Stock Option Plans on Stockholders and Bondholders. Journal of Finance 45: 617-27.

Fazzari, S., R. Hubbard, and B. Peterson. 1988. Investment, Financing Decisions, and Tax Policy. American Economic Review 78: 200-205.

Fazzari, S., R. Hubbard, and B. Peterson. 2000. Investment-Cash Flow Sensitivities Are Useful: A Comment on Kaplan and Zingales, Quarterly Journal of Economics (May): 695705.

Froot, K., D. Scharfstein, and J. Stein. 1993. Risk Management: Coordinating Corporate Investment and Financing Policies. Journal of Finance 48:1629-1657. 
Gaver, J., and K. Gaver. 1993. Additional Evidence on the Association Between the Investment Opportunity Set and Corporate Financing, Dividend, and Compensation Policies. Journal of Accounting and Economics 16 (January/April/July): 125-60.

Geczy, C., B. Minton, and C. Schrand. 1997. Why Firms Use Currency Derivatives. Journal of Finance 52: 1323-54.

Guay, W. 1999. An Empirical Analysis of the Convexity between Stock Price and CEO's Wealth. Journal of Financial Economics. 53: 43-71.

Harris, M. and A. Raviv. 1991. The Theory of Capital Structure. Journal of Finance 46: 297-356.

Hausman, J. 1978. Specification Tests in Econometrics. Econometrica 46: 207-218.

Haugen, R. and L. Senbet. 1981. Resolving the Agency Problems of External Capital through Options. Journal of Finance 36: 629-48.

Haushalter, D. 2000. Financing Policy, Basis Risk, and Corporate Hedging: Evidence from Oil and Gas Producers. Journal of Finance 55(1): 107-152.

Hemmer, T., O. Kim, and R.E. Verrecchia. 1999. Introducing Convexity into Optimal Compensation Contracts, Journal of Accounting And Economics 28(3): 307-327.

Hirshleifer, D. and R. Suh. 1992. Risk, Managerial Effort, and Project Choice. Journal of Financial Intermediation 2: 308-45.

Holthausen, R., D. Larcker, and R. Sloan. 1995. Business Unit Innovation and the Structure of Executive Compensation. Journal of Accounting And Economics 19: 279-313.

Indjejikian, R. 1999. Performance Evaluation and Compensation Research: An Agency Perspective. Accounting Horizons 13(2): 147-57.

Ittner, C. and D. Larcker. 2001. Assessing Empirical Research in Managerial Accounting: A Value-Based Management Perspective. Journal of Accounting and Economics (forthcoming).

Jensen, M. and W. Meckling. 1976. Theory of the Firm: Managerial Behavior, Agency Costs and Ownership Structure. Journal of Financial Economics 3: 305-60.

Kaplan, S. and L. Zingales. 1997. Do Investment-Cash Flow Sensitivities Provide Useful Measures of Financing Constraints? Quarterly Journal of Economics, 169-215.

Kaplan, S. and L. Zingales. 2000. Investment-Cash Flow Sensitivities are not Valid Measures of Financing Constraints. Quarterly Journal of Economics (May): 707-712.

Kennedy, P. 1998. A Guide to Econometrics, $4^{\text {th }}$ edition. Cambridge, MA: MIT Press.

Lambert, R. 1986. Executive Effort and the Selection of Risky Projects. Rand Journal of Economics 17: 77-88. 
Lambert, R., D. Larcker, and R. Verrecchia. 1991. Portfolio Considerations in Valuing Executive Compensation. Journal of Accounting Research 29: 129-149.

Larcker, D. 1983. The Association Between Performance Plan Adoption and Corporate Capital Investment. Journal of Accounting And Economics 5: 3-30.

Leland, H. 1998. Agency Costs, Risk Management, and Capital Structure. Journal of Finance 53: 1212-43.

Merton, R. 1973. Rational Option Pricing. Bell Journal of Economics and Management Science 4: 373-413.

Mian, S. 1996. Evidence on Corporate Policy. Journal of Financial and Quantitative Analysis 31: 419-439.

Murphy, K. 1998. Executive Compensation. Working paper. University of Southern California, Los Angeles, CA.

Nance, D., C. Smith, and C. Smithson. 1993. On the Determinants of Corporate Hedging. Journal of Finance 48: 267-284.

Rajgopal, S. 1999. Early Evidence on the Informativeness of the SEC's Market Risk Disclosures: The Case of Commodity Price Risk Exposure of Oil and Gas Producers. The Accounting Review 74: 251-280.

Sharpe, S. and H. Nguyen. 1995. Capital Market Imperfections and Incentives to Lease. Journal of Financial Economics. 39: 271-294.

Skinner, D. 1996. Are Disclosures about Bank Derivatives and Employee Stock Options 'Value-Relevant'? Journal of Accounting and Economics 22: 393-405.

Smith, C., and R. Stulz, 1985. The Determinants of Firms' Hedging Policies, Journal of Financial and Quantitative Analysis 4: 391-405.

Smith, C., and R. Watts. 1992. The Investment Opportunity Set and Corporate Financing, Dividend, and Compensation Policies. Journal of Financial Economics 7: 117-61.

Sunder, S. 1976. Properties of Accounting Numbers Under Full Costing and SuccessfulEfforts Costing in the Petroleum Industry. The Accounting Review 51: 1-18.

Tufano, P. 1996. Who Manages Risk? An Empirical Examination of Risk Management Practices in the Gold Mining Industry. Journal of Finance 51: 1097-1137.

White, H. 1980. A Heteroscadasticity Consistent Covariance Matrix Estimator and a Direct Test for Heteroscadasticity. Econometrica 48: 817-38.

Yermack, D. 1995. Do Corporations Award CEO Stock Options Effectively? Journal of Financial Economics 39: 237-269. 


\section{Appendix: Computing coefficient of variation in future cash flows from exploration activities}

\section{Extract of SFAS 69 disclosures from the 1995 10-K filing of Newfield Exploration Company}

\section{a) Expected value of discoveries from exploration activity (xLN $-\mathrm{Nc}$ in equation 6 in the text)}

A summary of the changes in standardized measure of discounted future net cash flows applicable to proved oil and gas reserves is as follows (in thousands):

Year ended December

31,1995

Beginning of the period

$\$ 180,002$

Revisions of previous estimates:

Additions to proved reserves resulting from extensions, discoveries and

87,760

improved recovery, less related costs $(x \mathrm{LN} \theta-\mathrm{Nc})^{2_{3}}$

Other reasons for the change (suppressed here)

End of period

8,564
$\$ 276,326$

Therefore, $\mathrm{xLN} \theta$ is $\$ 87.76$ million $+\$ 32.50$ million (Nc i.e., exploration costs for 1995 reported separately by the firm as per SFAS 69$)=\$ 120.26$ million.

\section{b) Productive life of a well (L)}

Productive life of a well is computed as a weighted average of the estimated lives of oil wells and gas wells:

$\mathrm{L}=\mathrm{w}($ Beginning oil reserves /Oil production $)+(1-\mathrm{w})($ Beginning gas reserves /Gas production $)$

where $\mathrm{w}=($ Beginning oil reserves $) /($ Total beginning oil and gas reserves (expressed in equivalent barrels $))=8,610 /(8,610+19,294)=.31$.

$=.31(8,610 / 2,071)+.69(153,967 / 33,719)=4.438$ years (reserve and production numbers are drawn from other SFAS 69 disclosures in the firm's 10-K).

\section{c) Number of exploratory wells drilled $(\mathbf{N})$ and the success rate $(\theta)$}

\section{DRILLING ACTIVITY}

The following table sets forth the drilling activity of the Company for 1995

\footnotetext{
${ }^{23}$ Following Alciatore (1993, pp. 643, notes to her Table 1), we assume that the discoveries number shown in the appendix is discounted. Hence, our method of backing out $\mathrm{x}$ (see part $\mathrm{d}$ of the appendix) will understate the cash flow per well in proportion to well age. As a sensitivity check, we introduced well age computed in part $\mathrm{b}$ as a control variable in equation (3) and estimated the 2SLS system consisting of equations (3) and (4). Our results were qualitatively similar to those reported in Table 4. As expected, well age assumed a significant negative coefficient.
} 


\begin{tabular}{lrr} 
& \multicolumn{2}{c}{1995} \\
Exploratory wells: & GROSS & NET \\
Productive & 10 & 4.7 \\
Nonproductive & $\underline{6}$ & $\underline{3.9}$ \\
Total & $\underline{16}$ & $\underline{8.6}$
\end{tabular}

The number of exploratory wells $(\mathrm{N})$ is 8.6 and success rate $(\theta)$ is $4.7 / 8.6=54.6 \%$. ${ }^{24}$ Hence, 8.6 and $54.6 \%$ may be viewed as a realization from an underlying firm specific distribution of $\mathrm{N}$ and $\theta .5566$

\section{d) Expected value of cash flows per productive period (x)}

$\mathrm{x}$ is backed out as:

Future cash flows from exploration activity discoveries $(\mathrm{xLN} \theta)$ divided by

[Productive life of a well $(\mathrm{L}) *$ Number of exploratory wells drilled $(\mathrm{N}) *$ success rate $(\theta)$ ]

i.e., $\$ 120.26$ million $/(4.438$ years $* 8.6$ wells $* 0.546)=\$ 5.77$ million.

\section{e) Variance of future cash flows from exploration activity}

The variance is computed as $(x \operatorname{LN} \theta) * x(1-\theta)=x^{2} \operatorname{LN} \theta(1-\theta)=$

$\$ 120.26$ million $* \$ 5.77$ million $*(1-0.546)=\$ 315.03$ million.

\section{f) Coefficient of Variation}

Coefficient of variation from exploration $=$ Variance $($ from $e$ )/expected value of discoveries $=$ ExpRisk $=\$ 315.03$ million $/ 87.76$ million $=\mathbf{3 . 5 8}$.

\footnotetext{
${ }^{24}$ Firms frequently conduct exploration activities in an area as a part of a consortium with other producers. A gross well is a well in which an interest is owned by the firm. A net well represents the fractional interest owned in the gross well by the firm. We use the number of net wells to compute exploration success. To the extent our sample firms hold a fractional interest that results in them not being the decision agents, there is a bias against finding a positive relation between exploration risk and ESO risk incentives.

${ }^{25}$ Sunder (1976) assumes an exogenous inter-temporally constant success rate of exploration $(\theta)$ and then derives the theoretical coefficient of variation of cash flows from exploration activity (CV). To ensure variation in our exploration risk measure, we empirically allow $\theta$ and $\mathrm{CV}$ to vary every year. While such measurement is not strictly consistent with Sunder's theoretical assumption of an inter-temporally constant $\theta$, we believe that assessing the impact of a time-varying $\theta$ on the theoretical CV and accordingly constructing an empirical measure of $\mathrm{CV}$ is beyond the scope of our paper. Note also that annual computation of the variance measure has the advantage of incorporating the effect of changing oil prices on exploration risk. For example, success rate, $\theta$, and the economic life of the reserve, $\mathrm{L}$, would be higher in years where oil price levels are higher and vice-versa.

${ }^{26}$ If the number of exploratory wells drilled is 0 and or the success rate is 0 or 1 , the variance is set equal to 0 . It should be noted that the ExpRisk measure is set to zero for 14 CEO-year observations. Of these, for 8 CEO-years, the number of exploratory wells is 0 while the success rates are 0 or 1 for 6 CEO-years. Our results are insensitive to the inclusion or exclusion of these 14 observations.
} 
Table 1

Sample selection details and descriptive data on
select financial characteristics of sample firms

Panel A: Sample selection criteria

Oil and gas CEO-years on Execucomp

$\underline{\text { Total }}$

Less deletions

CEO-years missing CEO option data

11

CEO-years with 10-Ks but missing exploration risk data CEO-years with missing 10-Ks

160

Sample

5

$\underline{23} \quad \underline{39}$

$\underline{121}$

Sample

$\begin{array}{llllll}1993 & 1994 & 1995 & 1996 & 1997 & \text { Total }\end{array}$

Sample used in regressions*

$\begin{array}{llllll}21 & 25 & 27 & 26 & 22 & 121\end{array}$

* 4 firm-year observations omitted in the regressions identified using SAS influential diagnostics

Panel B: Selected financial data over the sample period 1993-1997 (\$millions except when stated, $\underline{\mathrm{N}=117)}$

\begin{tabular}{lrrrrr}
\hline & Mean & $\begin{array}{c}\text { Standard } \\
\text { deviation }\end{array}$ & $\begin{array}{c}10^{\text {th }} \\
\text { percentile }\end{array}$ & Median & \multicolumn{1}{c}{$\begin{array}{c}90^{\text {th }} \\
\text { percentile }\end{array}$} \\
\hline & & & & & \\
Sales & 528.83 & 642.29 & 54.40 & 234.95 & 1636.67 \\
Total assets & 1207.96 & 1231.54 & 162.65 & 676.61 & 3308.93 \\
Net Income & 15.73 & 155.25 & -57.56 & 16.54 & 140.01 \\
Book value of equity & 482.18 & 598.95 & 67.04 & 219.04 & 1416.00 \\
Market value of equity & 1262.92 & 1509.15 & 145.61 & 690.52 & 3163.32 \\
Return on Assets (\%) & 2.56 & 6.94 & -4.45 & 3.44 & 8.42 \\
\hline
\end{tabular}

Panel C: Descriptive data on annual CEO compensation over the sample period 1993-1997 (\$ thousands, $\mathrm{N}=117$ )

\begin{tabular}{|c|c|c|c|c|c|}
\hline & Mean & $\begin{array}{l}\text { Standard } \\
\text { deviation }\end{array}$ & $\begin{array}{c}10^{\text {th }} \\
\text { percentile }\end{array}$ & Median & $\begin{array}{c}90^{\text {th }} \\
\text { percentile }\end{array}$ \\
\hline Salary & 371.59 & 162.52 & 183.33 & 349.12 & 604.16 \\
\hline Bonus & 187.64 & 196.56 & 0 & 135.39 & 440 \\
\hline $\begin{array}{l}\text { Black Scholes value of new } \\
\text { option grants }\end{array}$ & 620.15 & 1365.39 & 0 & 324.65 & 1370.08 \\
\hline $\begin{array}{l}\text { Value of new restricted stock } \\
\text { grants }\end{array}$ & 102.98 & 457.28 & 0 & 0 & 168.75 \\
\hline
\end{tabular}


Table 2

Descriptive data on calculation of Exploration risk, ESO risk incentives, and control variables ( $n=117$ firm-year observations 1993-1997)

Panel A: Calculation of coefficient of variation of exploration risk (ExpRisk)

\begin{tabular}{|c|c|c|c|c|c|}
\hline & Mean & $\begin{array}{l}\text { Standard } \\
\text { deviation }\end{array}$ & $\begin{array}{c}10^{\text {th }} \\
\text { percentile }\end{array}$ & Median & $\begin{array}{c}90^{\text {th }} \\
\text { percentile }\end{array}$ \\
\hline $\begin{array}{l}\text { Variance of future cash flows from } \\
\text { exploration (\$ million) }\end{array}$ & 929.18 & 2595.34 & 0 & 165.86 & 1492.98 \\
\hline $\begin{array}{l}\text { Expected value of discoveries (\$ } \\
\text { million) }\end{array}$ & 176.16 & 214.08 & 16.06 & 97.00 & 501.00 \\
\hline Coefficient of variation (ExpRisk) & 3.45 & 5.87 & 0 & 1.59 & 8.93 \\
\hline $\mathrm{N}-$ no. of exploratory wells & 16.84 & 19.51 & 1 & 11.3 & 41 \\
\hline$\Theta$ - success rate & 0.51 & 0.21 & 0.28 & 0.50 & 0.81 \\
\hline L - well's age (years) & 9.39 & 4.72 & 5.59 & 8.74 & 13.92 \\
\hline Nc - Exploration cost (\$ million) & 42.56 & 46.46 & 2.70 & 28.65 & 95.97 \\
\hline $\mathrm{C}-$ Exploration cost per well ( $\$$ mill $)$ & 3.61 & 4.60 & 0.52 & 2.30 & 7.42 \\
\hline $\mathrm{X}$ - cash flow per year (\$ million) & 5.34 & 9.07 & 0.085 & 2.45 & 13.67 \\
\hline
\end{tabular}

See the appendix for details on computing the coefficient of variation of future cash flows from exploration (ExpRisk).

Panel B: Calculation of ESO risk incentives and other stock-based incentives

\begin{tabular}{|c|c|c|c|c|c|}
\hline & Mean & $\begin{array}{l}\text { Standard } \\
\text { deviation }\end{array}$ & $\begin{array}{c}10^{\text {th }} \\
\text { percentile }\end{array}$ & Median & $\begin{array}{c}90^{\text {th }} \\
\text { percentile }\end{array}$ \\
\hline ESO risk incentives $(\$ 000)$ & 30.97 & 41.48 & 0.04 & 17.66 & 71.09 \\
\hline Number of options (thousands) & 373.52 & 425.91 & 35 & 190 & 1060 \\
\hline Mean price-to-strike ratio & 1.19 & 3.94 & 0.72 & 1.66 & 3.13 \\
\hline Variance of stock returns (\%) & 18.33 & 11.56 & 6.27 & 16.61 & 33.84 \\
\hline ESO slope incentive $(\$ 000)$ & 58.67 & 69.32 & 2.96 & 28.04 & 161.52 \\
\hline $\begin{array}{l}\text { Black-Scholes value of total option } \\
\text { portfolio }(\$ 000)\end{array}$ & 3855.23 & 4826.10 & 164.69 & 1814.81 & 12323.09 \\
\hline Restricted stock slope incentive & 3.22 & 15.48 & 0 & 0 & 4.48 \\
\hline $\begin{array}{l}\text { Market value of restricted stock } \\
\text { holdings }(\$ 000)\end{array}$ & 322.73 & 1548.32 & 0 & 0 & 448.13 \\
\hline Stock slope incentive & 93.99 & 154.29 & 0.66 & 35.86 & 310.33 \\
\hline $\begin{array}{l}\text { Market value of stock holdings } \\
(\$ 000)\end{array}$ & 9399.17 & 15429.84 & 66.39 & 3586.51 & 31033.63 \\
\hline Total slope incentive & 155.89 & 178.46 & 10.65 & 89.15 & 362.25 \\
\hline $\begin{array}{l}\text { Total firm-specific CEO wealth } \\
(\$ 000)\end{array}$ & 13576.69 & 16918.77 & 634.38 & 5836.98 & 34982.66 \\
\hline
\end{tabular}


Panel C: Descriptive statistics of control variables used in exploration risk regression

\begin{tabular}{lrrrrr}
\hline & Mean & $\begin{array}{c}\text { Standard } \\
\text { deviation }\end{array}$ & $\begin{array}{c}10^{\text {th }} \\
\text { percentile }\end{array}$ & Median & $\begin{array}{c}90^{\text {th }} \\
\text { percentile }\end{array}$ \\
\hline BM & 0.42 & 0.18 & 0.23 & 0.41 & 0.64 \\
Exploration costs & 0.04 & 0.04 & 0.003 & 0.03 & 0.09 \\
IOS factor score & 0 & 1 & -0.85 & -0.34 & 1.14 \\
& & & & & \\
Cash balances (\$Mill) & 35.38 & 48.91 & 2.53 & 13.46 & 102.23 \\
Leverage & 0.67 & 0.45 & 0.19 & 0.54 & 1.31 \\
Log(total assets) & 6.55 & 1.12 & 5.09 & 6.51 & 8.10 \\
\hline
\end{tabular}

Notes: ESO risk incentives is measured as the sensitivity of the change in Black-Scholes option value to a $1 \%$ change in stock return volatility multiplied by the number of options in the CEO's portfolio (see Core and Guay 1998). Price-to-strike ratio is the year-end stock price divided by the exercise price of an option. The mean strike-to-price ratio is the weighted average of the price-to-strike ratio for all options in the CEO's option portfolio at fiscal year-end. Variance of stock returns is the variance of daily stock returns over the last 250 trading days of the year. The ESO slope incentive, restricted stock slope incentive and stock slope incentive are the change in value of the CEOs' holding of that equity instrument given a $1 \%$ change in stock price. The total slope incentive, the sensitivity of wealth to stock price, is the sum of the three slope components. Total firm-specific CEO wealth is the sum of the market value of the CEO's option holdings, restricted stock and common stock holdings. BM is book to market ratio measured at year-end. Exploration costs refers to total exploration costs for a year scaled by total assets at year-end. The IOS factor score is derived by conducting a factor analysis of the market to book ratio and exploration costs scaled by total assets. Cash balance represents cash and marketable securities at year-end. Leverage is long-term debt divided by market value of equity measured at year-end. 
Table 3

Evidence on the importance to managers of exploration risk Results of regressing exploration risk on stock return volatility

\begin{tabular}{|c|c|c|}
\hline Explanatory variables & Prediction & Slope estimate \\
\hline Intercept & $?$ & $\begin{array}{c}0.85 * * * \\
(0.31)\end{array}$ \\
\hline ExpRisk $_{\mathrm{t}}$ & + & $\begin{array}{c}0.005 * * \\
(0.002)\end{array}$ \\
\hline$\delta_{\text {oilt }}$ & + & $\begin{array}{l}0.19 * * \\
(0.10)\end{array}$ \\
\hline $\mathrm{BM}_{\mathrm{t}}$ & - & $\begin{array}{l}-0.06 \\
(0.06)\end{array}$ \\
\hline Leverage $_{t}$ & + & $\begin{array}{c}0.06^{* * * *} \\
(0.02)\end{array}$ \\
\hline $\log \left(\right.$ total assets $\left.\mathrm{t}_{\mathrm{t}}\right)$ & - & $\begin{array}{c}-0.07 * * * \\
(0.25)\end{array}$ \\
\hline $\begin{array}{l}\text { Adjusted R-squared (\%) } \\
\text { F-statistic }\end{array}$ & & $\begin{array}{c}33.00 \\
6.66\end{array}$ \\
\hline
\end{tabular}

$\left(\sigma_{t}\right)=$ standard deviation of daily stock returns, $\delta_{\text {oilt }}=$ oil price sensitivity for each firm $\mathrm{j}$ and year $\mathrm{t}$, computed from an extended market model using daily stock returns, daily market-index returns and daily percentage change in West Texas Intermediate grade of oil: $\mathrm{R}_{\mathrm{jt}}=\delta_{0 \mathrm{jt}}+\delta_{\mathrm{mktjt}} \mathrm{MKTRET}_{\mathrm{t}}+\delta_{\text {oiljt }} \Delta \% \mathrm{OPRICE}_{\mathrm{t}}+$ $\varepsilon_{\text {jt. }}$ ExpRisk is the coefficient of variation from exploration-related cash flows as illustrated in the appendix. See notes to Table 2 for the definitions of other variables. Number of observations used is 117. Standard errors are reported in the parentheses. $* / * * / * * *$ indicate significant $\mathrm{p}$ values at levels $0.10 / 0.05 / 0.01$ respectively. p-values are computed with heteroskedastic consistent standard errors. The stars reflect onetailed $\mathrm{p}$ values for variables with signs as predicted, two-tailed otherwise. Coefficients on year dummies not reported. 
Table 4: Analysis of Exploration risk and ESO risk incentives

Exploration risk regression: ExpRisk ${ }_{t+1}=\gamma_{0}+\gamma_{1}$ ESO risk incentives $_{t}+\gamma_{2}$ Leverage $_{t}+\gamma_{3}$ IOS factor score $_{t}+$ year dummies + error $_{t+1}$

ESO risk incentive regression: ESO risk incentive $e_{t}=\beta_{0}+\beta_{1}$ ExpRisk $_{t+1}+\beta_{2}$ IOS factor score $_{t}+$ $\beta_{3} \log (\text { assets })_{t}+\beta_{4}$ Sensitivity of wealth to stock price ${ }_{t}+\beta_{5}$ Cash compensation $_{t}+\beta_{6}$ Cash balance $_{t}+$ year dummies + error $_{t}$

\begin{tabular}{|c|c|c|c|c|}
\hline Model & \multicolumn{2}{|c|}{ Exploration risk regression } & \multicolumn{2}{|c|}{ ESO risk incentive regression } \\
\hline Dependent variable & \multicolumn{2}{|c|}{ ExpRisk $_{\mathrm{t}+1}$} & \multicolumn{2}{|c|}{ ESO risk incentive $_{t}$} \\
\hline Column & \multicolumn{2}{|c|}{ A } & \multicolumn{2}{|c|}{$\mathrm{B}$} \\
\hline $\begin{array}{l}\text { Intercept } \\
\text { Endogenous variables }\end{array}$ & $\begin{array}{c}\text { Pred. Sign } \\
?\end{array}$ & $\begin{array}{c}\text { Coeff. } \\
\text { (std error) } \\
1.309 \\
(1.721)\end{array}$ & $\begin{array}{c}\text { Pred. Sign } \\
?\end{array}$ & $\begin{array}{l}\text { Coeff. } \\
\text { (std error) } \\
-64.434 \\
(79.885)\end{array}$ \\
\hline ESO risk incentives $_{t}$ &,$+ \mathrm{H} 1$ & $\begin{array}{c}0.038 * * * \\
(0.014)\end{array}$ & & \\
\hline ExpRisk $_{\mathrm{t}+1}$ & & & + & $\begin{array}{l}-5.147 \\
(8.516)\end{array}$ \\
\hline Instruments & & & & \\
\hline Leverage $_{t}$ & + & $\begin{array}{c}2.833 * * \\
(1.471)\end{array}$ & & \\
\hline IOS factor score ${ }_{t}$ & + & $\begin{array}{l}0.521^{* *} \\
(0.311)\end{array}$ & + & $\begin{array}{l}5.042 * \\
(3.429)\end{array}$ \\
\hline $\log (\text { assets })_{t}$ & & & + & $\begin{array}{l}11.683 \\
(19.467)\end{array}$ \\
\hline Sens. of wealth to stock price ${ }_{t}$ & & & + & $\begin{array}{l}0.069^{* *} \\
(0.041)\end{array}$ \\
\hline Cash comp $_{\mathrm{t}}$ & & & $+/-$ & $\begin{array}{l}0.043^{* *} \\
(0.021)\end{array}$ \\
\hline Cash balance $_{t}$ & & & - & $\begin{array}{c}0.031 \\
(0.108)\end{array}$ \\
\hline $\begin{array}{l}\text { Hausman (1978) simultaneity } \\
\text { test } p \text { value }\end{array}$ & & 0.04 & & 0.78 \\
\hline Adjusted $\mathrm{R}^{2}$ & & $10.35 \%$ & & $32.18 \%$ \\
\hline
\end{tabular}

Notes: The equations are estimated using two-stage least squares. Number of observations used is 117. Standard errors are reported in the parentheses. $* * * / * * *$ indicate significant $\mathrm{p}$ values at levels $0.10 / 0.05 / 0.01$ respectively. $p$-values are computed with heteroskedastic consistent standard errors. The stars reflect one-tailed $\mathrm{p}$ values for variables with signs as predicted, two-tailed otherwise. Cash comp is the sum of salary and bonus. ExpRrisk is the coefficient of variation from exploration-related cash flows as illustrated in the appendix. See notes to Table 2 for the definitions of the remaining variables. Coefficients on year dummies are not reported. 


\section{Table 5: Analysis of oil price risk hedging and ESO risk incentives}

Hedge ratio regression: Hedge ratio ${ }_{\mathrm{t}}=\delta_{0}+\delta_{1} \mathrm{ESO}$ risk incentives $\mathrm{t}_{\mathrm{t}}+\delta_{2}$ IOS factor score $\mathrm{t}_{\mathrm{t}}+\delta_{3} \log (\operatorname{assets})_{\mathrm{t}}$ $+\delta_{4}$ Leverage $_{\mathrm{t}}+\delta_{5}$ Divpayout $_{\mathrm{t}}+\delta_{6}$ Quickratio $_{\mathrm{t}}+\delta_{7}$ O\&G Sales $\%_{\mathrm{t}}+$ year dummies + error $_{\mathrm{t}}$

ESO risk incentive regression ESO risk incentives $t_{t}=\beta_{0}+\beta_{1}$ Hedge ratio ${ }_{t}+\beta_{2}$ IOS factor score se $_{t}+\beta_{3}$ $\log (\text { assets })_{\mathrm{t}}+\beta_{4}$ Sensitivity of wealth to stock price $\mathrm{t}_{\mathrm{t}}+\beta_{5}$ Cash compensation $_{\mathrm{t}}+\beta_{6}$ Cash balances $_{\mathrm{t}}+$ year dummies + error $_{\mathrm{t}}$

\begin{tabular}{|c|c|c|c|c|}
\hline Model & \multicolumn{2}{|c|}{ Hedge ratio regression } & \multicolumn{2}{|c|}{ ESO risk incentive regression } \\
\hline Dependent variable & \multicolumn{2}{|c|}{ Hedge ratio } & \multicolumn{2}{|c|}{ ESO risk incentive $_{t}$} \\
\hline Column & \multicolumn{2}{|r|}{$\mathrm{A}$} & \multicolumn{2}{|c|}{$\mathrm{B}$} \\
\hline $\begin{array}{l}\text { Intercept } \\
\text { Endogenous variables }\end{array}$ & $\begin{array}{c}\text { Pred. } \\
\text { Sign } \\
?\end{array}$ & $\begin{array}{c}\text { Coeff. } \\
\text { (std error) } \\
-0.110^{*} \\
(0.066)\end{array}$ & $\begin{array}{c}\text { Pred. Sign } \\
?\end{array}$ & $\begin{array}{c}\text { Coeff. } \\
\text { (std error) } \\
-9.298 \\
(16.454)\end{array}$ \\
\hline ESO risk incentives $_{t}$ & - & $\begin{array}{c}-0.0016 * * * \\
(0.0003)\end{array}$ & & \\
\hline Hedge ratio ${ }_{t}$ & & & - & $\begin{array}{l}80.545 \\
(136.66)\end{array}$ \\
\hline Instruments & & & & \\
\hline IOS factor score ${ }_{t}$ & + & $\begin{array}{l}0.011^{*} \\
(0.007)\end{array}$ & + & $\begin{array}{l}2.159^{*} \\
(1.648)\end{array}$ \\
\hline $\log (\text { assets })_{t}$ & + & $\begin{array}{l}0.018 * * \\
(0.009)\end{array}$ & + & $\begin{array}{l}-1.053 \\
(3.213)\end{array}$ \\
\hline Leverage $_{t}$ & + & $\begin{array}{l}-0.013 \\
(0.013)\end{array}$ & & \\
\hline Divpayout $_{t}$ & - & $\begin{array}{l}0.0009 \\
(0.007)\end{array}$ & & \\
\hline Quick ratio $_{t}$ & - & $\begin{array}{c}-0.035^{* * *} \\
(0.011)\end{array}$ & & \\
\hline O\&G Sales $\%_{\mathrm{t}}$ & + & $\begin{array}{l}-0.001 \\
(0.024)\end{array}$ & & \\
\hline Sens. of wealth to stock price ${ }_{t}$ & & & + & $\begin{array}{c}0.018 \\
(0.018)\end{array}$ \\
\hline Cash comp $_{t}$ & & & $+/-$ & $\begin{array}{c}0.049 * * * \\
(0.014)\end{array}$ \\
\hline Cash balance $_{\mathrm{t}}$ & & & - & $\begin{array}{c}-0.116^{* *} \\
(0.054)\end{array}$ \\
\hline $\begin{array}{l}\text { Hausman (1978) simultaneity test p- } \\
\text { value }\end{array}$ & & 0.02 & & 0.45 \\
\hline Adjusted $\mathrm{R}^{2}$ & & $9.14 \%$ & & $38.61 \%$ \\
\hline
\end{tabular}

Notes: The equations are estimated using two-stage least squares. Number of observations used is 117. Standard errors are reported in the parentheses. $* / * * / * * *$ indicate significant $\mathrm{p}$ values at levels $0.10 / 0.05 / 0.01$ respectively. $p$-values are computed with heteroskedastic consistent standard errors. The stars reflect one-tailed $p$ values for variables with signs as predicted, two-tailed otherwise. Hedge ratio is the quantity of reserves hedged scaled by the quantity of proven reserves held by the firm at year-end, Divpayout is the dividends paid scaled by earnings before extraordinary items, Quick ratio is the ratio of cash and shortterm investments at the end of year divided by current liabilities at the end of year, O\&G Sales \% is the percentage of the firm's sales in year that are attributable to sale of oil and gas. See notes to Table 2 for the definitions of the remaining variables. Coefficients on year dummies are not reported. 